\title{
Meio semi-seletivo para detectar Xanthomonas axonopodis pv. phaseoli em sementes de feijoeiro e sua erradicação através do tratamento de sementes com o fungicida tolylfluanid
}

\author{
Lucilene Paula Lopes; Priscila Fernanda Rocha Alves; Carla Zandoná; Maria Paula Nunes; Yeshwant Ramchandra Mehta
}

Instituto Agronômico do Paraná - IAPAR, Caixa Postal 481, Londrina, PR., Brasil. E-mail: yrmehta@iapar.br Autor para correspopndência: Yeshwant Ramchandra Mehta. yrmehta@iapar.br Data de chegada: 23/05/2006. Aceito para publicação em: 15/05/2008

\section{RESUMO}

Lopes, L.P.; Alves, P.F.R.; Zandoná, C.; Nunes, M.P.; Mehta, Y.R. Meio semi-seletivo para detectar Xanthomonas axonopodis pv. phaseoli em sementes de feijoeiro e sua erradicação através do tratamento de sementes com o fungicida tolylfluanid. Summa Phytopathologica, v.34, n.3, p.287-288, 2008

Estudou-se a eficiência do meio semi-seletivo desenvolvido para Xanthomonas axonopodis pv. malvacearum (Xam) do algodoeiro, com algumas modificações, na detecção de Xanthomonas axonopodis pv. phaseoli (Xap) em sementes de feijoeiro, bem como a eficiência do fungicida tolylfluanid na erradicação de Xap através do tratamento de sementes. Foram utilizadas sementes naturalmente infectadas por Xap, procedentes de diferentes municípios do Estado do Paraná. Houve o desenvolvimento de colônias bacterianas ao redor das sementes infectadas sob meio semi-seletivo entre seis e 12 dias de incubação. A frequiência de recuperação de colônias da bactéria em relação ao meio Agar nutriente (AN) variou entre 30 a $112 \%$. O crescimento de Xap foi inibido a concentrações entre 54 a 1500 ppm do fungicida tolylfluanid. A bactéria foi recuperada das sementes não tratadas em meio semi-seletivo, mas não das sementes tratadas em solução do fungicida tolylfluanid (1,20g/L água). Em casa de vegetação, das 400 sementes tratadas com tolylfluanid não foi produzida nenhuma planta com sintomas da doença até 30 dias após a semeadura, enquanto que $9,75 \%$ das sementes não tratadas apresentaram sintomas de Xap. Em um outro experimento, das 1200 sementes não tratadas um total de $7,08 \%$ e $11,67 \%$ das plantas mostraram-se com sintomas da doença, enquanto que das sementes tratadas $0,5 \%$ e $2,4 \%$ apresentaram sintomas, 26 e 46 dias após a semeadura, respectivamente.

Palavra chave adicionais: Crestamento bacteriano comum, Phaseolus vulgaris

\section{ABSTRACT}

Lopes, L.P.; Alves, P.F.R.; Zandoná, C.; Mehta, Y.R. A semi-selective medium to detect Xanthomonas axonopodis pv. phaseoli in bean seeds and its eradication through seed treatment with tolylfluanid. Summa Phytopathologica, v.34, n.3, p.287-288, 2008

The efficiency of a semi-selective medium developed for Xanthomonas axonopidis pv. malvacearum (Xam), was verified with some modifications, in detecting the presence of $X$. axonopodis $\mathrm{pv}$. phaseoli (Xap) in bean seed. Seed samples naturally infected with Xap were collected from the State of Paraná. The bacterial growth developed around the infected seed in the semi-selective medium after 12 days after incubation. The recovery frequency of bacterial colonies in relation to nutrient agar varied between 30 and $112 \%$, depending upon the isolate. Efficiency of tolylfluanid to eradicate Xap from the bean seed was also verified in laboratory and glasshouse experiments. The bacteria was recovered from the untreated seeds, but not from the seeds treated in a solution of tolylfluanid $(1.20 \mathrm{~g} / \mathrm{L}$ water), and placed in plates containing semi-selective medium. In the glasshouse, seeds treated with tolylfluanid, did not produce any symptoms of the disease till 30 days after seeding, whereas untreated seeds yielded $9,75 \%$ plants with typical disease symptoms. In an another experiment, untreated seeds yielded $7,08 \%$ and $11,67 \%$ diseased plants, whereas treated seeds yielded $0,5 \%$ and $2,4 \%$ diseased plants, 26 and 46 days after planting, respectively.
A semente do feijoeiro (Phaseolus vulgaris) é um veículo importante para a disseminação de Xanthomonas axonopodis pv. phaseoli (Xap), agente causal do crestamento bacteriano comum em feijoeiro cultivado em diversas regiões do mundo. O patógeno pode ser transmitido interna e externamente pela semente, sendo esta a fonte principal de inoculo primário da doença $(2,6)$. As cultivares mais comercializadas do feijoeiro são suscetíveis e a doença não é controlada por meio da utilização de produtos químicos. Desta forma, o controle depende basicamente do uso de sementes totalmente livres da bactéria $(2,3,4)$. Mehta et al. \& Clafin et al. $(5,2)$ desenvolveram um meio semi-seletivo para detectar a presença de X. axonopodis pv. malvacearum (Xam) e nas sementes do algodoeiro e para Xap nas sementes do feijoeiro. O objetivo do presente trabalho foi verificar a eficiência do meio desenvolvido por Mehta et al. (5) para isolamento de Xam, com algumas modificações, na detecção de Xap em sementes do feijoeiro e a eficiência de tolylfluanid na erradicação da bacteriose 
transmitida pela semente.

Para verificar a eficiência do meio semi-seletivo para Xap foram analisados lotes de sementes de feijoeiro das cultivares Carioca I, Carioca II, Carioca III, Carioca Pitoco, IAPAR 44 e IAPAR 81, das safras 2003-2004. Quatrocentas sementes de cada amostra foram desinfetadas e isoladas em placas de Petri contendo meio de cultura semi-seletivo, em quatro repetições (100 sementes por repetição). A composição do meio de cultura utilizado foi o mesmo daquele desenvolvido por Mehta et al. (5) para Xam, porém foi eliminado o tolylfluanid. As placas foram incubadas por doze dias a $24^{\circ} \mathrm{C}$ no escuro e as colônias suspeitas de Xap desenvolvidas ao redor das sementes foram isoladas para sua identificação por meio das características culturais, teste de Gram e teste de patogenicidade. Para a patogenicidade, plantas da cv. Carioca, com 10-12 dias de idade, foram inoculadas com uma suspensão de cada colônia suspeita por pulverizador manual. Como testemunha para a detecção de Xap, 50 g de sementes naturalmente infectadas por Xap foram incubadas em $100 \mathrm{ml}$ de solução salina esterilizada, por 16h, à temperatura ambiente e em agitador automático (150 rpm). A suspensão bacteriana obtida foi repicada em meio semi-seletivo por diluição serial $\left(10^{-4}, 10^{-5}, 10^{-6}\right.$, $10^{-7}$ ) e também foi utilizada para inoculação por pulverização manual de plantas de feijoeiro na casa de vegetação. A eficiência do meio de cultura foi determinada em comparação com a repicagem da bactéria em Agar nutriente (AN), como meio de cultura padrão, e foi avaliada mediante a contagem de colônias de Xap na diluição em serie.

Para verificar a eficiência de tolylfluanid na erradicação de Xap das sementes foram realizados três experimentos. No experimento I foi utilizado o método de disco de papel filtro embebido em suspensão de Xap $\left(10^{6} \mathrm{UFC} / \mathrm{ml}\right)$, colocando-os em placas de Petri contendo meio peptona-sacarose-agar (PSA) com concentração de tolylfluanid variando de 54 a $1500 \mathrm{ppm}$. Durante quatro gerações de sete dias de incubação, os discos foram transferidos, invertidos ou não, sucessivamente em novas placas contendo PSA sem tolylfluanid e o crescimento de Xap em cada geração foi anotado. No experimento II, sementes naturalmente infectadas por Xap foram colocadas em solução de tolylfluanid (1,2g/L água) por $6 \mathrm{~h}$. As sementes foram desinfestadas conforme Mehta et al. (5), secadas por algumas horas em condições assépticas, e colocadas em placas de Petri contendo meio semiseletivo sem tolylfluanid, em quatro repetições (100 sementes por repetição). As placas foram examinadas 12 dias após incubação no escuro a $24^{\circ} \mathrm{C}$, e as colônias suspeitas de Xap foram isoladas para sua identificação baseada nas características culturais determinantes, teste de Gram e de patogenicidade em casa de vegetação. No experimento III 1200 sementes da cv. Carioca Pitoco, tratadas e não tratadas com tolylfluanid por $16 \mathrm{~h}(1,2 \mathrm{~g} / \mathrm{L})$, foram semeadas em bandejas de plástico contendo solo esterilizado em casa de vegetação com três repetições (400 sementes por repetição e 100 sementes por bandeja). Trinta dias após o plantio as plantas foram examinadas e folhas com os sintomas da doença foram levadas para o laboratório onde o patógeno foi isolado e sua identidade foi confirmada como sendo Xap. As médias de plantas com sintomas da doença por tratamento foram comparadas entre si (teste de Tukey). O experimento foi repetido utilizando sementes da cv.
Carioca I.

A bactéria desenvolveu-se ao redor das sementes infectadas em meio semi-seletivo entre seis e 12 dias de incubação. As colônias suspeitas de Xap eram levemente amarelas, lisas, convexas, brilhantes e semelhantes a uma cultura típica de Xap da coleção do IAPAR. Todas as colônias morfologicamente suspeitas de Xap eram Gram negativas e patogênicas. A frequiência de recuperação de colônias de Xap variou entre 30 a $112 \%$. Alguns isolados mostraram pequena sensibilidade ao meio semi-seletivo, não obstante, o mesmo permitiu a recuperação de todos os isolados de Xap.

A ação de tolylfluanid como bactericida contra Xap foi confirmada nos três experimentos. No experimento I a bactéria não foi recuperada dos discos, durante as quatro gerações sucessivas. Sementes tratadas com tolylfluanid não produziram nenhuma colônia de Xap, enquanto que sementes não tratadas produziram em média 0,6 a 9,0 colônias de Xap, conforme observado no experimento II, demonstrando eficiência de $100 \%$ no tratamento de sementes com tolylfluanid. Da mesma forma, no isolamento por diluição serial não foi recuperada nenhuma colônia de Xap das sementes tratadas, enquanto as sementes não tratadas produziram entre $1,3 \times 10^{4} \mathrm{e} 10,4 \times 10^{4} \mathrm{ufc} / \mathrm{ml}$. No experimento III os primeiros sintomas da doença foram visíveis 25 dias após o plantio. As sementes da cv. Carioca Pitoco tratadas não produziram nenhuma planta com sintomas da doença até 30 dias após o plantio, enquanto que $9,75 \%$ das sementes não tratadas apresentaram plantas com sintomas típicos de Xap. Quando o experimento foi repetido com sementes da cv. Carioca I, as bandejas com sementes não tratadas mostraram um total de $11,67 \%$ de plantas com sintomas, enquanto as bandejas com sementes tratadas mostraram $2,4 \%$ de plantas com sintomas da doença 30 dias após a semeadura. A alta eficiência de tolylfluanid como bactericida contra Xap foi verificada. O tolylfluanid é comercializado para tratamento de sementes do algodoeiro, feijoeiro e soja, entre outros, e controla alguns patógenos fúngicos transmitidos pelas sementes (1).

\section{REFERÊNCIAS BIBLIOGRÁFICAS}

1. Bayer. Correio Agrícola. A revista da Bayer Crop Science para a agriculturamoderna, Editora Bayer, São Paulo, SP. Edição, p. 26-27. 2003.

2. Clafin, L.E.; Vidaver, A.K.; Sasser, M. MXP. A semi-selective medium for Xanthomonas campestris pv. phaseoli. Phytopathology, St. Paul, v. 77, p.730-734, 1987.

3. Maringoni, A.C. Virulência de isolados de Xanthomonas campestris pv. phaseoli (Smith) Dye em fejoeiro. Pesquisa Agropecuária Brasileira, Brasília, DF, v. 33, p. 861-867, 1998.

4. Maringoni, A.C.; Fregonese, L.H.; Tofolo, J.G.; Kurozawa, C. Reação foliar e da vagem de feijoeiro à Xanthomonas campestris pv. phaseoli e transmissão da bactéria pelas sementes. Fitopatologia Brasileira, Lavras, MG, v. 18, p. 412-415, 1993.

5. Mehta, Y.R.; Bomfete, C.; Bolognini, V. A semi-selective agar medium to identify the presence of Xanthomonas axonopodis pv. malvacearum in naturally infected cotton seed. Fitopatologia Brasileira, Lavras, MG, v. 30, p. 489-496, 2005.

6. Weller, D.M.; Saettler, A.W. Evaluation seed-borne Xanthomonas phaseoli and $X$. phaseoli var. fuscans as primary inocula in bean blights. Phytopathology, St. Paul, v. 70, p. 148-152, 1998. 